\title{
Utilization of biologically treated organic waste on land
}

Holm, Peter Engelund; Jensen, Lars Stoumann; McLaughlin, Michael J.

Published in:

Solid waste technology \& management

Publication date:

2010

Document version

Early version, also known as pre-print

Citation for published version (APA):

Holm, P. E., Jensen, L. S., \& McLaughlin, M. J. (2010). Utilization of biologically treated organic waste on land.

In T. H. Christensen (Ed.), Solid waste technology \& management (pp. 665-682). Wiley. 


\title{
9.10
}

\section{Utilization of Biologically Treated Organic Waste on Land}

\author{
Peter E. Holm and Lars Stoumann Jensen \\ University of Copenhagen, Denmark \\ Michael J. McLaughlin \\ CSIRO Land and Water/University of Adelaide, Australia
}

Biologically treated organic waste can be recycled back to agriculture and forestry for use on land. The organic waste products considered are processed (composted or anaerobically digested) or unprocessed organic waste from households, gardens, commerce and industry. Agricultural production waste and manure from conventional and organic animal production systems (cattle, pig, poultry slurry) are also used on land, but are not included in this chapter. The use of household wastes in agriculture is not widespread (but is increasing due to urban recycling programs) and most of the regulation in this field arises from the application of wastewater treatment sludges to agricultural land.

Organic wastes can also be beneficially used in urban areas, provided they have been processed is some way, e.g. through composting. Waste composts may be used for soil manufacturing, improvement of degraded urban soils, for soil improvement in parks, gardens and recreational areas, and for revegetation of disturbed soils, e.g. roadways, embankments, etc. These applications are described in Chapter 9.9.

From a historical perspective, land application of waste is as old as agriculture. The Chinese have used human and household waste as a fertilizer for thousands of years. In the beginning of the twentieth century, land application of sludge and waste in Europe and the United States was common. In those times the benefits of the waste were appreciated, and local farmers were glad to use waste or residuals to improve crop yields. However, as soon as concentrated and highly effective sources of plant nutrients became available and affordable in the form of chemical fertilizers, in many situations waste was seen as a disposal problem rather than a resource.

Solid Waste Technology and Management Edited by Thomas Christensen (C) 2010 Blackwell Publishing Ltd 


\subsubsection{Introduction}

The soil-plant-animal system offers an excellent opportunity for the application and reuse of constituents present in household waste materials, for example in agricultural crop production or in forestry (silviculture). Biologically treated household waste contains organic matter and essential plant nutrients including nitrogen $(\mathrm{N})$, phosphorus $(\mathrm{P})$, potassium $(\mathrm{K})$, sulfur (S), and trace elements. It is therefore potentially useful as a fertilizer and soil conditioner, and may potentially substitute the use of mineral fertilizers to greater or lesser extent. This depends both on the size and type of urban dwelling producing the waste (quantity, quality, concentration of nutrients in the waste) and the type of land use in the area where the waste could be applied (horticultural, arable, grassland, forest). In periurban areas of large cities, with only scattered agricultural or horticultural production, a substantial proportion of regional fertilizer demand could potentially be replaced with nutrients in biologically treated organic waste. However, in areas of intensive agricultural or horticultural production, nutrients in the organic household waste may contribute only a smaller fraction of regional demand, and may furthermore compete with agricultural wastes, such as livestock manures, for available land suitable for land application (see Box 9.10.1 for a more detailed case study).

\section{Box 9.10.1 Case Study Denmark: The Role of Waste as a Potential Nutrient Source for Crops.}

Magid et al., (2006) investigated the potential for use of N, P, and K which can be recovered from urban areas (in sewage and organic household waste) to replace mineral fertilizer currently used in agriculture in the Danish counties. They found that urban organic waste sources could potentially cover the need for $79 \%$ of current agricultural mineral fertilizer $\mathrm{N}$ use in the Copenhagen metropolitan area, with approximately 1.5 of Denmark's 5.2 million inhabitants (see figure below). However, in the remaining parts of the country, dominated by intensive agricultural production, organic waste sources would be able to substitute around $10 \%$ of mineral fertilizer $\mathrm{N}$ demand.

This was also generally the case for $\mathrm{K}$, but a larger proportion of crop $\mathrm{P}$ demand could potentially be covered from organic waste, in the Copenhagen metropolitan area actually as much $170 \%$, so in excess of local agricultural $\mathrm{P}$ demand. On average $22 \%$ of the national $\mathrm{P}$ demand could be covered.

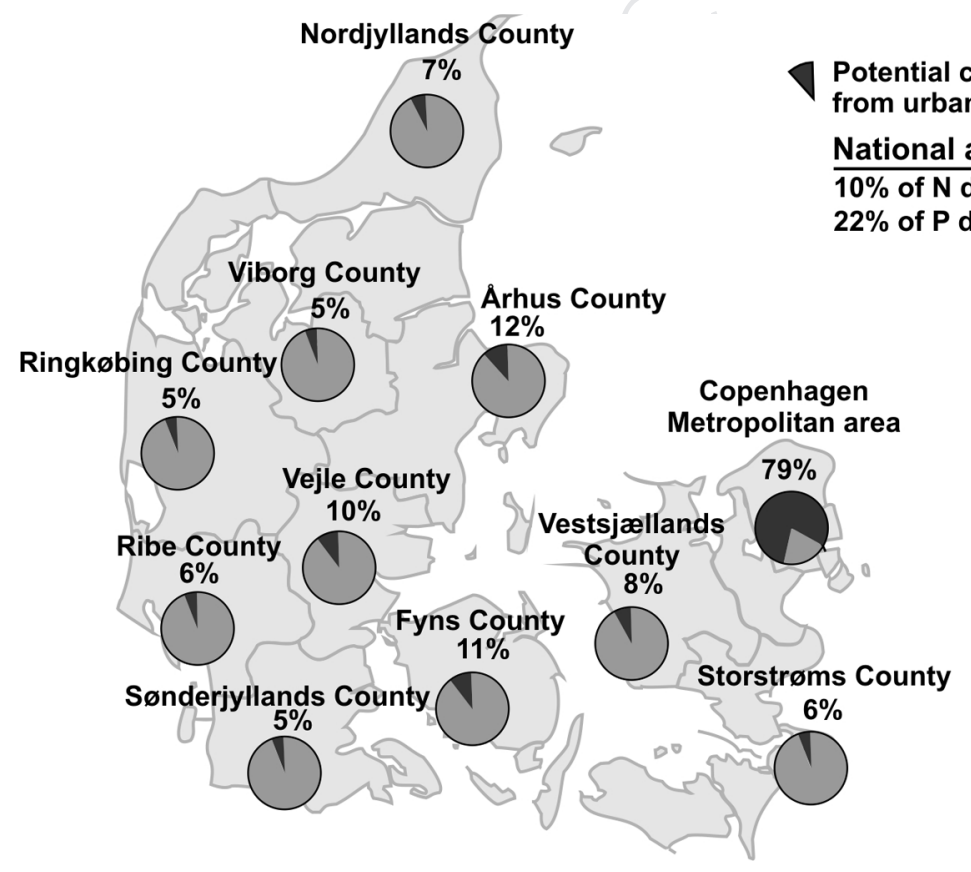

Bornholms County

$7 \%$

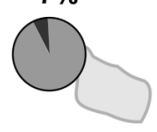


In agricultural production systems, 'closing' the cycling of nutrients is a continuing goal, so that losses of nutrients from the system (to the atmosphere, to water supplies or to sediments) are minimized. Closing the cycle for $\mathrm{P}$ is of particular interest, since it is an essential and nonreplaceable plant nutrient, and most of the world's soils have low available $\mathrm{P}$ levels, limiting crop production. Fertilization with $\mathrm{P}$ is therefore crucial for global food security, with world food demand expected to increase more than $50 \%$ before 2050 . However, $\mathrm{P}$ is a limited natural resource, with the mineable phosphate-rich rocks used for $\mathrm{P}$ fertilizer production projected to be exhausted within the next 60-130 years (Steen, 1998). Therefore, appropriate recycling of $\mathrm{P}$ is crucial and will increase in importance in the coming decades.

While recycling of wastes to agricultural systems will assist with closing of the $\mathrm{P}$ cycle, use of household wastes may cause environmental problems related to the presence of some constituents in the waste (e.g. household chemicals, pesticides, detergents, etc.) or imbalances between nutrient elements, especially if these cause potential pollution problems and have a negative impact on soil functions. Land application of waste is regulated in most countries to protect human health, the environment and the soil functionality from undesirable chemical constituents such as metals, e.g. cadmium (Cd) and lead $(\mathrm{Pb})$, toxic organic chemicals, e.g. polychlorinated biphenyls (PCBs), eutroficants (e.g. nitrate), and pathogens such as bacteria, e.g. Escherichia coli and viruses, e.g. Hepatitis A virus (Epstein, 2003).

Control of use of wastes on land includes regulatory measures concerning quantity (annual and maximum applied quantities) and quality (characteristics, pollutant level) of the waste being applied. Other measures include use of good management practices at land application sites (e.g. season for application, establishment of buffer zones).

Most of the waste products presently applied to agricultural soils are sludges from municipal wastewater treatment plants. In addition, there are other waste products, e.g. sludges from industries and composted organic wastes, which are applied in accordance with individual approvals by environmental authorities. During recent years, a number of initiatives have been taken regarding separation of waste at source. The organic waste products, e.g. food and vegetable waste are composted and reused in gardens, parks or on farmlands. The quality of the compost depends considerably on the efficiency of the separation at the source and on the treatment methods.

Table 9.10.1 presents typical characteristics of waste and manure applied to agricultural land.

Table 9.10.1 Characteristics of anaerobic digestate (household waste), sewage sludge, composts (organic household, green/garden waste) and animal slurries (pig, cattle). Based on numerous sources (e.g. Pedersen, 1999; Poulsen, 2009).

\begin{tabular}{|c|c|c|c|c|c|c|}
\hline & $\begin{array}{l}\text { Anaerobic digestate } \\
\text { (household waste) }\end{array}$ & $\begin{array}{c}\text { Sewage sludge/ } \\
\text { biosolids (treated?) }\end{array}$ & $\begin{array}{l}\text { Compost (organic } \\
\text { household waste) }\end{array}$ & $\begin{array}{l}\text { Compost (green/ } \\
\text { garden waste) }\end{array}$ & Pig slurry & Cattle slurry \\
\hline Total solids, $\%$ ww & $1-2$ & $2-30$ & $40-75$ & $50-75$ & $2.5-6.5$ & $6.5-10.5$ \\
\hline Volatile solids, \% TS & 65 & $40-80$ & $35-70$ & $20-40$ & $80-90$ & $75-85$ \\
\hline $\mathrm{N}$-total, \% TS & 3.5 & $2-5$ & $1.0-2.5$ & $0.7-1.6$ & $7.5-15.0$ & $3.8-6.9$ \\
\hline $\mathrm{N}-\mathrm{NH}_{4}, \% \mathrm{TS}$ & 1.7 & 0.01 & $<0.2$ & - & $5.6-11.3$ & $2.3-4.1$ \\
\hline $\mathrm{N}-\mathrm{NO}_{3}, \% \mathrm{TS}$ & $0.2-1.0$ & 0.005 & - & - & 0 & 0 \\
\hline $\mathrm{N}$-organic, \% TS & 1.8 & $2-5$ & - & - & $1.9-3.8$ & $1.5-2.8$ \\
\hline P-total, \% TS & 0.9 & $0.5-3.0$ & $0.2-1.0$ & $0.15-0.7$ & $1.8-2.8$ & $0.9-1.1$ \\
\hline $\mathrm{K}, \% \mathrm{TS}$ & 3.7 & $0.1-1.0$ & $0.5-2.0$ & $0.8-1.9$ & $3.8-6.5$ & $3.9-6.5$ \\
\hline C, $\%$ TS & 39 & - & $20-45$ & $10-30$ & 38 & 36 \\
\hline $\mathrm{H}, \% \mathrm{TS}$ & 5 & - & - & - & nd & nd \\
\hline S, \% TS & 0.5 & $0.4-2.0$ & $0.06-0.3$ & $0.1-0.15$ & 1 & 0.6 \\
\hline $\mathrm{Cl}, \% \mathrm{TS}$ & 2.9 & - & 0.3 & $0.001-0.1$ & 1.3 & 1.3 \\
\hline $\mathrm{C} / \mathrm{N}$-total ratio & 11 & $5-20$ & $12-20$ & $10-30$ & $3-5$ & $5-10$ \\
\hline $\mathrm{C} / \mathrm{N}$-organic ratio & - & nd & - & - & $10-20$ & $13-25$ \\
\hline $\mathrm{Mg}, \% \mathrm{TS}$ & $0.8-1.1$ & $0.1-0.5$ & $0.3-1.6$ & $0.3-0.4$ & 0.8 & 0.6 \\
\hline $\mathrm{Ca}, \% \mathrm{TS}$ & $2-5$ & $1-5$ & $3-7$ & $2.2-3.0$ & 2.5 & 1.4 \\
\hline $\mathrm{Pb}, \mathrm{mg} / \mathrm{kg}$ TS & $10-60$ & 15-100 & $25-110$ & $20-55$ & 3.3 & 3.4 \\
\hline $\mathrm{Cd}, \mathrm{mg} / \mathrm{kg}$ TS & $0.3-0.7$ & $0.5-5.0$ & $0.3-1.0$ & $0.2-0.5$ & 0.5 & 0.5 \\
\hline $\mathrm{Cr}, \mathrm{mg} / \mathrm{kg} \mathrm{TS}$ & - & $10-70$ & $15-40$ & $15-35$ & 10.3 & 2.5 \\
\hline $\mathrm{Cu}, \mathrm{mg} / \mathrm{kg}$ TS & $45-125$ & 100-1000 & $28-47$ & $28-50$ & 325 & 12.5 \\
\hline $\mathrm{Ni}, \mathrm{mg} / \mathrm{kg} \mathrm{TS}$ & $8-28$ & $7-100$ & $8-25$ & $6.3-8.3$ & 13.8 & 6.5 \\
\hline $\mathrm{Hg}, \mathrm{mg} / \mathrm{kg} \mathrm{TS}$ & - & $0.2-3.0$ & $0.1-0.3$ & $0.05-0.1$ & nd & nd \\
\hline $\mathrm{Zn}, \mathrm{mg} / \mathrm{kg} \mathrm{TS}$ & $150-300$ & 400-1000 & $120-270$ & $100-200$ & 750 & 150 \\
\hline
\end{tabular}




\subsubsection{Basic Principles of Agricultural and Forestry Land Application}

Application of treated organic waste to agricultural and forestry land offers benefits, but may also constitute some problems if not properly constrained. The basic issues are presented below.

\subsubsection{Basic Principles: Benefits}

Biologically treated waste contains several plant macronutrients, primarily $\mathrm{N}$ and $\mathrm{P}$, some $\mathrm{K}$, and varying amounts of micronutrients, such as boron $(\mathrm{B})$, copper $(\mathrm{Cu})$, iron $(\mathrm{Fe})$, manganese $(\mathrm{Mn})$, molybdenum $(\mathrm{Mo})$, and zinc $(\mathrm{Zn})$. The amounts and ratios of nutrients do not match a well formulated chemical fertilizer, but the soil is usually supplied with supplementary nutrient from other fertilizers to provide the proper amounts of nutrients needed for crop production. Soil incorporation of processed organic solid waste usually results in a positive effect on the growth and yield of a wide variety of crops and may contribute to the restoration of ecological and economic functions of degraded land.

Agricultural uses of municipal solid waste (MSW) have shown promise for a variety of field crops (e.g. maize, sorghum, forage grasses) and vegetable for human consumption (e.g. lettuce, cabbage, beans, potatoes, cucumbers; Shiralipour et al., 1992). The fertilizer value (yield or nutrient uptake per unit of nutrient applied, relative between organic and commercial mineral fertilizer) of MSW and sludges range from the negligible or even negative to more than $50 \%$ of commercial mineral fertilizers, in particular if the residual release of nutrients in subsequent years is included.

Application of biologically treated waste can also improve soil structure. The addition of organic materials like compost to a fine-textured soil can assist the development of structure (aggregation) and can stabilize soil aggregates against dispersion. Improvement of the structure of the soil makes it more friable (lower soil strength, desirable for cultivation and seedbed preparation) and increase the amount of pore space available for plant roots and the entry of water and air into the soil. In coarse-textured sandy soils, organic matter can increase the water holding capacity of the soil and provide exchange and adsorption sites for nutrients. Furthermore, added organic matter may prevent erosion and therefore assist revegetation of sloping land. A major benefit of organic wastes in more arid climates is their use as mulches for water conservation and for modulation of variations in surface soil temperatures. Water requirements and weed infestation of crops can be markedly reduced by mulching with organic wastes (e.g. Preusch and Twokoski, 2003), as can diurnal variations in surface soil temperatures (Dahiya et al., 2001).

As for agricultural land, the advantage of applying organic waste in forestry (silviculture) is the addition of plant macro- and micronutrients. Since forests are often planted on infertile and poorly structured soils (sandy, low pH soils), tree growth is often limited by nutrient deficiencies. Consequently, organic waste can provide a good source of nutrients and organic matter and can be an inexpensive alternative to conventional fertilizers. Because trees are perennials, the scheduling and management of waste applications is not as complex as it may be for annual crops. Application of wastes to forest soils is generally performed either annually or at 2- to 5-year intervals.

Land application of organic wastes may also contribute positively to long-term stabilization of carbon (C) in the soil and hence to decrease atmospheric $\mathrm{CO}_{2}$ levels (Smith et al., 2001). Carbon dioxide from degraded fresh organic matter is considered neutral with respect to the global warming impact, because the plants have recently removed an equal amount of carbon dioxide from the atmosphere during growth. Thus, organic matter from treated waste stored in the soil represents a 'saved' emission of carbon dioxide. This mechanism is referred to as carbon sequestration and carbon is sequestered (protected) in soils as soil organic matter.

Comprehensive model simulations of the soil turnover of applied $\mathrm{C}$ in anaerobically treated sewage sludge have shown that $63-86 \%$ is still stabilized in the soil after 10 years, but only $17-37 \%$ after 50 years, and $10-14 \%$ after 100 years (Bruun et al., 2006; see further information in Box 9.10.2). An experimental study of sewage sludge inputs over 30 years (Tian et al., 2009) indicated an average $\mathrm{C}$ sequestration rate of approximately 30-35\% of annual applied C, confirming the simulation results. However, $\mathrm{C}$ is not sequestered infinitely, and soil $\mathrm{C}$ reaches a new equilibrium with decomposition, where no further increase is achieved. However, even with the low net $\mathrm{C}$ storage simulated after 100 years (Bruun et al., 2006), this corresponds to an avoided $\mathrm{CO}_{2}$ emission of approximately $180 \mathrm{~kg} \mathrm{CO}_{2} / \mathrm{t}$ dry matter of sewage sludge applied to the soil. 


\section{Box 9.10.2 Environmental Impacts from Soil Application of Processed Organic Waste.}

The principles of life cycle assessment (LCA) can be used to quantify and assess the environmental impacts, including any environmental benefits from a substitution of the use of chemical fertilizers. Basically, LCA accounts for all uses of resources and all emissions from the waste application and fertilizer on land, accumulated through the lifetime of the applied waste. Hansen et al. (2006) applied such LCA principles for assessing the environmental impacts of application of processed organic waste to agricultural land, including substitution of commercial fertilizer and soil carbon sequestration. Environmental impacts included in the use on land submodel of the EASEWASTE LCA model (Kirkeby et al., 2006) are illustrated in the figure below.

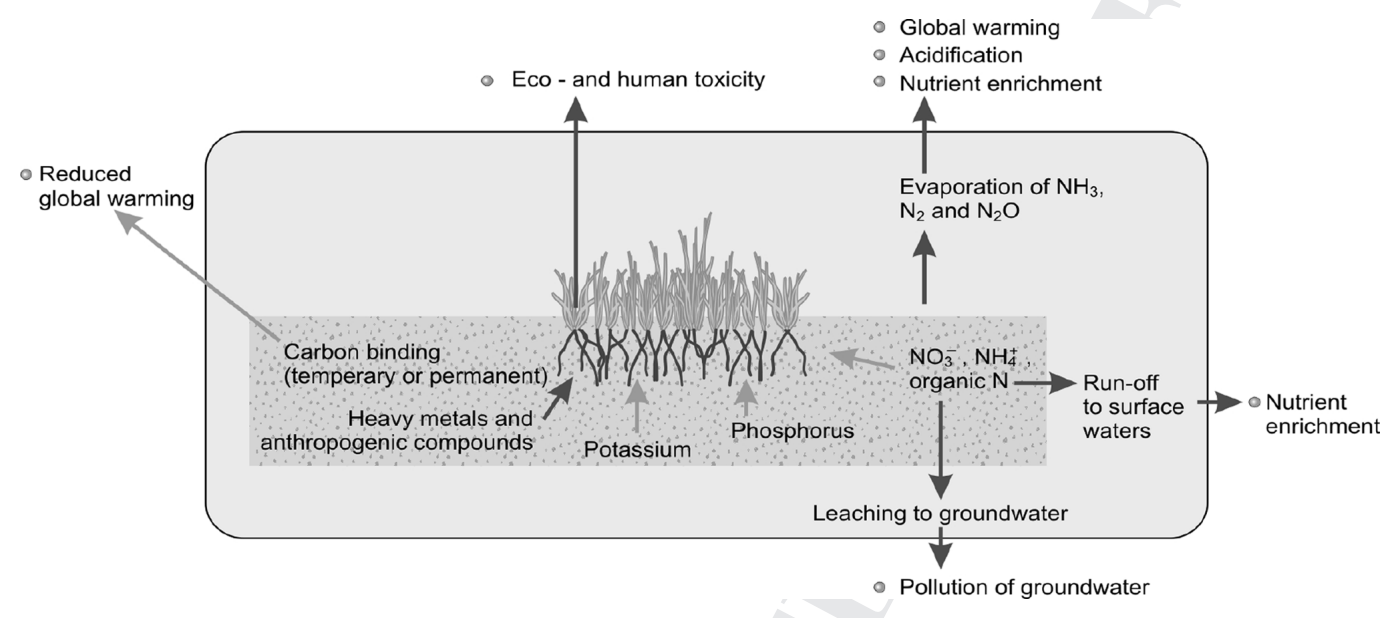

A range of Danish land use scenarios with differing climates, soils, farm types, crop rotations and livestock densities were simulated with a dynamic, mechanistic agroecosystem model (viz Daisy; Bruun et al., 2006) in order to determine emission factors, graduated according to local conditions, and these were then applied in the LCA model. The left figure below shows how large an influence e.g. the time frame of the simulated soil $\mathrm{C}$ sequestration factor (and hence the amount of waste $\mathrm{C}$ stored in soil) has on the global warming potential impact. The right figure illustrates the large influence of soil type and waste decomposition characteristic on particularly the nutrient enrichment potential, leading to eutrophication of the aquatic environment (negative values are savings).
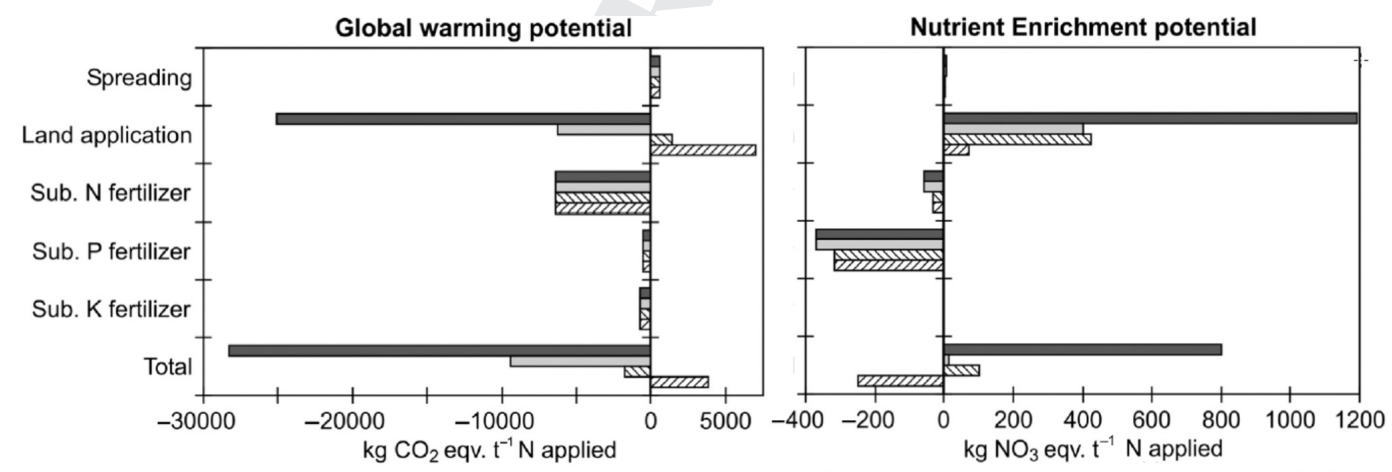

$\square 10$ years $\square 50$ years $\mathbb{\nabla} 100$ years $\square$ Infinite time

$\square$ Anaerobic digestion residue applied to loamy soil $\square$ Anaerobic digestion residue applied to sandy soil $\triangle$ Compost applied to loamy soil ๑ Compost applied to sandy soil 


\subsubsection{Basic Principles: Constraints}

Although the waste is produced at no cost for the land user, the financial cost of the land application may be a major constraint for reuse. The costs may involve control and regulatory measures and fees, taxes, etc., which may exceed the economic benefits. Also, most organic wastes are bulky, low-grade fertilizers of variable composition and frequently have high water content. Accordingly, they cannot be transported very far before transportation costs exceed the fertilizer value. The fossil fuel-derived $\mathrm{CO}_{2}$ emissions from transport (also termed the carbon footprint) should also be factored into decisions about waste reuse schemes. Many waste-producing facilities lack agricultural and forestry land within economically practical transportation distances.

In addition, application scheduling that is compatible with agricultural and forestry planting, climatic conditions, and harvesting requires careful management. This will often limit application on arable land to a certain months, e.g. under temperate, humid climate in autumn or early spring, and may introduce significant costs for storage facilities. Furthermore, some of the nutrients in organic wastes are not readily available for plant uptake, but must be mineralized first.

Organic wastes contain various compounds (metals, organics, see also section on pollutants) that may pose potential environmental and human health risks. In particular, urban wastes may contain relatively high concentrations of potentially toxic metals which may accumulate in surface soils as metals generally bind strongly to soil particles. Potentially toxic metals may extinct or inhibit bacterial species responsible for important soil functions (see Box 9.10.3) and could have significant negative effects on the soil ecosystem to support plant production (e.g. Brandt et al., 2006).

Organic wastes, in particular sewage sludge, may contain a number of organisms pathogenic to humans, e.g. viruses, bacteria and parasites. In addition, organic waste materials may also carry plant pathogenic fungi, bacteria, and weed seeds, which adversely affect crop production. However, various forms of biological treatment of the waste can reduce

\section{Box 9.10.3 Soil Functionality and Land Uses (Compiled by Hansen, 2001).}

Soils are natural entities and represent nonrenewable natural resources at least on a time scale of hundred to thousands of years. About $99 \%$ of the world's food and fiber are produced on soil/land. However, land also has functions or uses other than serving food production.

In general the following functions can be distinguished:

F1: Production of biomass (food, fiber and other nonfood).

F2: Clearing and filtering (mineralization, attenuation of pollutants).

F3: Habitat for plants and animals (maintenance of high biological diversity, gene reserve).

F4: Sites for construction of houses, roads and landfills.

F5: Resource of raw material such as minerals, construction materials (e.g. sand and gravel).

F6: Cultural archive storing remnants of historical activities of man.

The interest in the environmental roles played by soils is not new but has markedly intensified due to the side effects of the technological revolution in the agricultural sector taking place after the Second World War. This revolution introduced the common use of fertilizers and pesticides, and it gave rise to farm units with high animal densities producing large amounts of manures.

There is an increasing awareness of the limits for biomass production set by the other soil functions, in particular F2 and F3. The European community seeks to sustain agricultural production governed by the sustainability criterion. It implies that the quality of the soil resource must not degrade over time and that soil resources shall be managed in a way that minimizes adverse effects in the neighboring aqueous and atmospheric environments.

In addition more interest is now being paid to food quality and health. Therefore the application of pesticides, fertilizers and wastes on land is now under fairly strict control to prevent eutrophication and pollution of the environment and to secure soil functionality and food quality. 
these risks significantly (see below), and for some of the pathogens, varying degree of inactivation will also occur shortly after soil application. The risk of transfer of pathogens into the human food chain is greater when the waste is applied to an edible crop, compared to a feed crop used for livestock production, and hence the former is prohibited in many countries.

While reuse of organic wastes in forestry situations eliminates any risks from transfer of contaminants through the human food chain, the risks from nutrient and contaminant runoff and leaching remain. Forest ecosystems are often characterized by relatively low nutrient requirements and have low exports of nutrients (and potential pollutants). Hence, increasing the import of organic matter and nutrients on relatively poor forest soils may increase the leaching of potential pollutants such as metals to groundwater, see e.g. Andersen et al. (2002). In many soils, leaching of nutrients, especially nitrate, to groundwater may also limit the application rate.

Many organic wastes contain soluble salts, which can cause problems in their use as fertilizers, particularly in arid regions where soluble salts are already present in irrigation waters (Weggler et al. 2004). These can not only cause salt damage to crops through osmotic stress, but may also mobilize contaminants in the soil (e.g. Cd).

Odors and associated nuisances from application of organic waters to land, both real and imagined, create conflict. Often odors are the major obstacle for gaining public and farmer acceptance for waste reuse in agricultural systems, especially those in close proximity to residential areas.

\subsubsection{Land Use of Biologically Treated Waste}

As described above, the use of wastes may cause problems related to their composition because of undesirable chemical and biological constituents. Land application of waste is therefore regulated in most countries to protect human health, the environment and the soil functionality from the possible negative impact of these constituents, refer to Box 9.10 .3 (Soil functionality and land uses) for further details. This section focuses on the soil function of biomass production in relation to agriculture and forestry. As stated earlier, the characteristics of a given treated waste product are dependent upon the origin of the waste and the process by which it is produced. A wide range of physical, biological, and chemical characteristics have to be taken into considerations when using waste on land (Table 9.10.2). These characteristics are further described in detail.

Table 9.10.2 Waste parameters used for defining physical, biological and chemical characteristics.

\begin{tabular}{ll}
\hline Parameter/characteristics & Purpose \\
\hline Physical & \\
Color & Aesthetics \\
Odor & Aesthetics, Health, marketability \\
Bulk density & Transportation, handling, application \\
Moisture or dry matter content & Handling \\
Organic matter/volatile solids content & Soil structure and quality \\
Particle size distribution & Handling, aesthetics, soil structure and quality \\
Water holding capacity & Water conservation \\
Biological & \\
Pathogens (bacteria, viruses, prions) & Health, environment, agronomic value \\
Seed germination & Soil quality, crop production \\
Weed seeds & Soil quality, crop production \\
Chemical & \\
Nutrient contents (macro and micro) & Agronomic fertilizer value, soil quality \\
Soluble salts/electric conductivity & Agronomic value, soil quality \\
Heavy metals & Health, environment, agronomic value \\
Organic pollutants & Health, environment, agronomic value \\
\hline
\end{tabular}




\subsubsection{Physical Properties}

The desired physical characteristics of treated organic waste by farmers are usually dark color, uniform particle size, earthy odor, low moisture content, and high organic matter content.

The application of biologically treated organic wastes can improve soil structure. The added organic matter enhances both aggregate formation (the binding of fine particles together) and stability (resistance to dispersion). Improvement of the structure of the soil will make it more friable and increase the amount of pore space available for plant roots and the entry of water and air into the soil. In coarse-textured sandy soils, organic matter can increase the water holding capacity of the soil and provide exchange and adsorption sites for nutrients. Furthermore, the organic waste may prevent erosion and therefore assist efforts to revegetate eroded soils.

In arid regions with limited water supplies, organic wastes used as mulches (surface applications of 5-15 cm depth) are often beneficial in reducing evaporation from the soil surface, thus reducing water requirements and providing a buffer from temperature extremes at the soil surface. This is often beneficial for seed germination and early seedling growth. An additional benefit is that soils in arid regions are often low in organic matter, with low water holding capacities. Addition of organic wastes to these soils is particularly beneficial.

\subsubsection{Biological Properties}

Addition of compost or other processed organic waste affects soil biology, fertility and quality (see Box 9.10.4 for further details) in both positive and negative ways. Organic waste application stimulates soil microbial and faunal (especially earthworm) activity, and hence improves soil fertility, as these soil organisms play central role in mineralization and turnover of organically bound nutrients. A recent study (Saison et al. 2006) found that compost amendment affected the activity, size and composition of the soil microbial community but the effect was mainly due to the physicochemical properties of the compost matrix and the stimulation of native soil microorganisms by available substrate, rather than to compost-borne microorganisms themselves.

\section{Box 9.10.4 Soil Biology, Fertility, and C and N Cycling.}

Soil biota includes:

- Fauna (animals) in size from earthworms to single-celled protozoan.

- Flora (plants) includes the roots of higher plants as well as microscopic algae.

- Microorganisms including fungi and bacteria which tend to predominate in terms of both numbers, mass and metabolic capacity.

Soil fertility refers to the inherent ability of a soil to act as growth medium for plants, including the capacity of the soil to supply nutrients to plants in adequate amounts and suitable proportions. A high level of soil fertility in a soil plant system requires a suitable soil depth for unlimited root growth, suitable mechanical properties, $\mathrm{pH}$, temperature and aeration, high plant available water capacity, and nontoxic concentrations of metals, salts or other contaminants. Finally, fertile soils are able to supply plants with an adequate and a balanced supply of elements throughout the whole growth period. The latter is closely related to the soil biota, as the biogeochemical cycles of $\mathbf{C}, \mathbf{N}, \mathbf{S}$ and $\mathbf{P}$ are intrinsically linked to biotic activity and associated organic matter turnover.

Agricultural practices have different effects on different organisms, and hence on cycling of C, N, S and P, but a few generalizations can be made (Brady and Weil, 2002).

- Monocultures of crops generally reduce the diversity of soil organisms as well as the number of individuals. However, monoculture may increase the population of a few species. 
- Adding inorganic lime and fertilizers to an infertile soil generally will increase microbial and faunal activity, but largely due to the increase in the plant biomass that is likely to be returned to the soil as roots, root exudates and shoot residues.

- Adding organic fertilizers, such as sludges, biosolids and animal manures, to an infertile soil will however influence microbial and faunal activity directly, as they provide organic components serving as substrate for the microorganisms and fauna.

- Tillage tends to increase the microbial degradation of organic matter in the soil, and the role of bacteria increases at the expense of the fungi and usually decreases overall organism's number as the soil C pool is depleted.

However, organic waste materials may also contain unwanted biota, which include parasites and pathogens of man and animals such as bacteria (e.g. Salmonella, Campylobacter, Enterococcus), viruses, and parasites (e.g. Ascaris). The bacterium Escherichia coli is a normal constituent of the intestinal flora of man and farm animals, but it does not occur in large numbers in uncontaminated soil or water (Stevenson and Cole, 1999), and as such it is commonly used as an easily detectable indicator for fecal pathogen presence. Biological treatment, e.g. biological oxidation (degradation) of organic waste by composting or aeration prior to application to land most often aims to reduce or eliminate these pathogens. Elimination depends on a number of factors, including $\mathrm{pH}$, temperature and retention time of the biological treatment. Figure 9.10.1 illustrates how various combinations of temperature and retention time may be used to safely kill off all relevant pathogens, e.g. $70^{\circ} \mathrm{C}$ for $<1 \mathrm{~h}, 55^{\circ} \mathrm{C}$ for $>1$ day or $45^{\circ} \mathrm{C}$ for $>1$ month (Strauch, 1998). The latter temperature-time combinations illustrates that thermophilic digestion in a biogas plant $\left(\right.$ at $52-55^{\circ} \mathrm{C}$ ) in many cases may result in hygienization or pasteurization of the waste. Hygienization may also be achieved by increasing the pH to e.g. 12 by liming or other alkaline agents (Carrington, 2001).

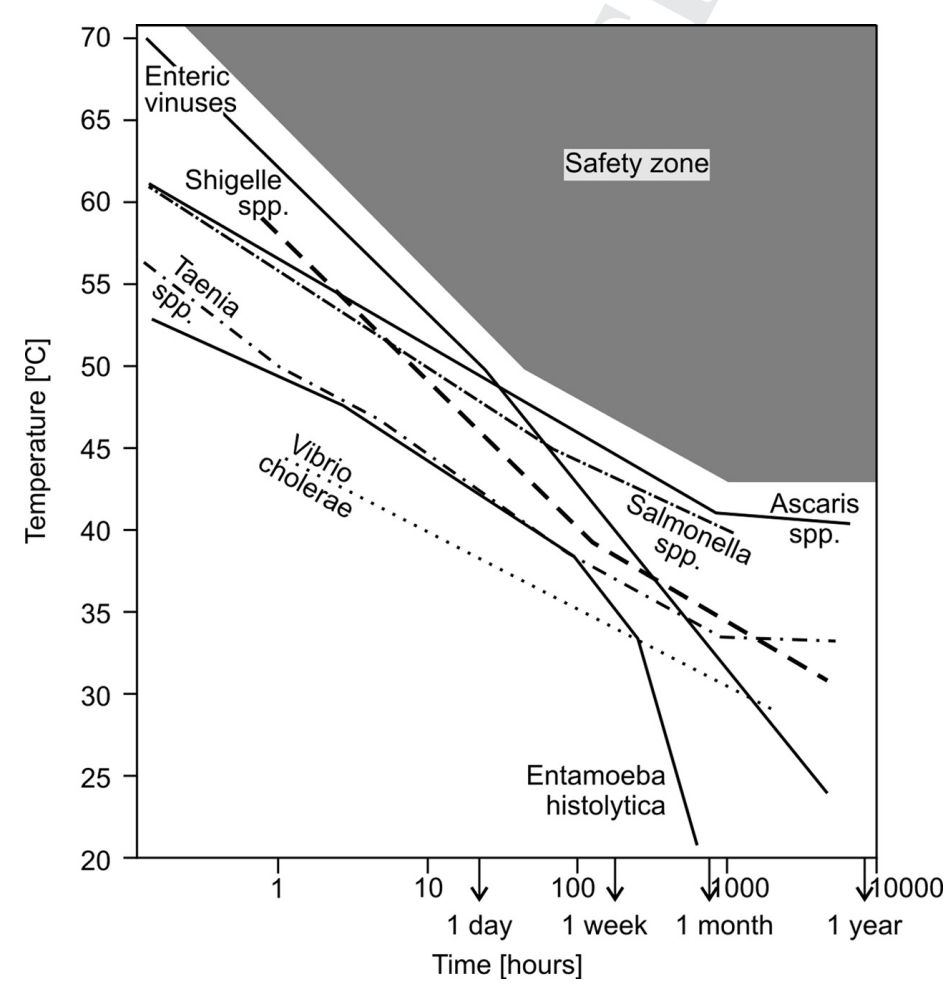

Figure 9.10.1 Time-temperature relation for safe kill-off for various pathogens in sewage sludge (Strauch, 1998). 
Once applied to soils, a relatively quick die off of most pathogens occurs, due to competitive advantage of native organisms present in agricultural and forest soils. The survival time for most waste-borne microorganisms following land application is usually very short (hours to days), but a few species, like the persistent E. coli $\mathrm{O} 157: \mathrm{H} 7$ has been shown to be able to survive somewhat longer (several months, Avery et al., 2005). Generally, survival depends on a variety of soil and climatic conditions including temperature, moisture content, and $\mathrm{pH}$. Low temperature and high soil moisture result in the longest survival of pathogens.

\subsubsection{Chemical Properties and Fertilizer Value}

The agronomic value of applying treated waste is mainly related to its chemical composition, and to its soil physical conditioning value. The three major plant nutrients are nitrogen $(\mathrm{N})$, phosphorus $(\mathrm{P})$, and potassium $(\mathrm{K})$, of which in 2008 approximately 199 million $\mathrm{Mg}$ (quantity of $\mathrm{N}+\mathrm{P}_{2} \mathrm{O}_{5}+\mathrm{K}_{2} \mathrm{O}$ ) in inorganic commercial fertilizers are applied throughout the world (FAO, 2008) to ensure sufficient food production and economically profitable crop yields for the farmers. Evaluating the agronomic value of waste on land relies very much on an evaluation of the ability of the waste to supply $\mathrm{N}, \mathrm{P}$, and $\mathrm{K}$ to crops in terms of commercial fertilizer equivalence.

The nutrient contents of industrial sludges and biosolids from sewage treatment plants vary considerably with ranges (dry matter basis) of $1-200 \mathrm{~g} / \mathrm{kg}$ for total $\mathrm{N}, 0.005-70.0 \mathrm{~g} / \mathrm{kg}$ for $\mathrm{NH}_{4}-\mathrm{N}$ and $0.002-5.0 \mathrm{~g} / \mathrm{kg}$ for NO $\mathrm{NO}_{3}-\mathrm{N}, 1-150 \mathrm{~g} / \mathrm{kg}$ for total P, and $0.2-25.0 \mathrm{~g} / \mathrm{kg}$ for $\mathrm{K}$ being reported (e.g. Pierzynski and Gehl, 2005). Considering most crop requirement for $\mathrm{N}, \mathrm{P}$, and $\mathrm{K}$, biosolids contain a high concentration of $\mathrm{P}$ compared to $\mathrm{N}$ and $\mathrm{K}$. This is because $\mathrm{N}, \mathrm{K}$ (and $\mathrm{S}$ ) to some extent partition to the liquid phase (sewage effluent) during sewage treatment, or are lost from the biosolids during processing (e.g. denitrification for $\mathrm{N}$ ). Potassium is generally retained relatively strongly (by cation exchange as $\mathrm{K}^{+}$ on soil clays) after application to land, and $\mathrm{K}$ is not regarded as a major water pollutant. On the other hand, $\mathrm{N}$ and $\mathrm{P}$ may be lost from the biosolid or sludge-amended soil by both leaching $(\mathrm{N})$ and surface runoff $(\mathrm{N}$ and $\mathrm{P}$ ). Thus it is critical that loadings of both $\mathrm{N}$ and $\mathrm{P}$ are chosen with careful consideration of crop demand and potential leaching/runoff losses. In the European Union, the Nitrates Directive imposes a limit for $\mathrm{N}$ application in manures and organic waste of $170 \mathrm{~kg} \mathrm{~N} / \mathrm{ha} /$ year.

The organic $\mathrm{N}$ in sludge is not immediately available for plant uptake, and the mineralization process which converts organic $\mathrm{N}$ into plant available ammonium $\left(\mathrm{NH}_{4}{ }^{+}\right)$and subsequently nitrate $\left(\mathrm{NO}_{3}{ }^{-}\right.$; see reaction scheme in Box 9.3.1, which is also valid for soil) is slow compared to the timing of plant need for inorganic $\mathrm{N}$ for most annual, agricultural crops. This means that only $30-40 \%$ of the $\mathrm{N}$ in sewage sludge is mineralized within 3-4 months (Epstein 2003), and hence be available for the crop to which it was applied, whilst the rest of the $\mathrm{N}$ is only slowly released during subsequent years. In a humid climate, this may consequently contribute to nitrate leaching to the subsoil and groundwater if released outside the growing season of crops.

The first year fertilizer $\mathrm{N}$ equivalent value, i.e. the amount of mineral fertilizer $\mathrm{N}$ [in the form of $\mathrm{NH}_{4} \mathrm{NO}_{3},\left(\mathrm{NH}_{4}\right)_{2} \mathrm{SO}_{4}$ or urea $\mathrm{CO}\left(\mathrm{NH}_{2}\right)_{2}$ ] that $100 \mathrm{~kg}$ total $\mathrm{N}$ in sludge or biosolids may replace, has been found to be around 26-37\% when applied in Spring and only 16-23\% when applied in Autumn, in a number of Danish field experiments (Pedersen, 1999). Similar results in other temperate, humid climates have been found by others (Petersen, 2003; Gilmour et al., 2004). In comparison, somewhat higher first year fertilizer $\mathrm{N}$ equivalent values may be achieved for animal manures, ranging from $40 \%$ for solid farmyard manures up to as much as $75 \%$ for liquid slurries, if applied appropriately (minimal $\mathrm{N}$ losses and in synchrony with crop demand). This is mainly due to the fact that a higher proportion of manure $\mathrm{N}$ is already in the form of ammonium at the time of application.

However, the residual fertilizer $\mathrm{N}$ equivalent value (i.e. the extra $\mathrm{N}$ availability from mineralization of organic biosolid $\mathrm{N}$ in subsequent years) from biosolids has been found to be considerably higher (7-15\% in the second year, 5-7\% in the third year after application) than typically found for animal manures (Pedersen, 1999), again under temperate, humid conditions. The accumulated fertilizer $\mathrm{N}$ equivalent value over several years may therefore well reach $45-60 \%$ or even higher as shown by Binder et al. (2002), provided losses from leaching prevailing under these climatic conditions can be minimized.

Phosphorus in sludges and biosolids exists in both inorganic and organic forms with the inorganic forms generally predominating (Hedley and McLaughlin, 2005). Organic P must undergo mineralization in the soil before the $\mathrm{P}$ is available for plant uptake, similar to organic $\mathrm{N}$, but generally the total $\mathrm{P}$ application rates are much higher than crop needs when 
sludge application is based on the management of $\mathrm{N}$. Compared with commercial mineral phosphate fertilizers, mainly comprised of mono- and diammonium phosphates biosolid fertilizer $\mathrm{P}$ value first of all depends on whether it is derived from a sewage plant with biological treatment only or with chemical biological treatment using coagulants like $\mathrm{Fe} / \mathrm{Al}$ salts (e.g. Pierzynski and Gehl, 2005). The former typically yields biosolids with a high P availability, corresponding more or less to mineral fertilizer P (McLaughlin and Champion, 1987). Iron and aluminium coagulants, in contrast, yield $\mathrm{P}$ precipitates of low solubility, depending on the degree of Fe/Al surplus used in the process. These P salts will only have a low and more long-term fertilizer value.

Sewage sludges are generally considered to be poor sources of $\mathrm{K}$, primarily due to the low concentrations of $\mathrm{K}$ in sludges. Despite having low $\mathrm{K}$ concentrations, the $\mathrm{K}$ in sludges is often a soluble constituent and considered to be fully available for plant uptake, similar to commercial mineral fertilizers such as $\mathrm{KCl}, \mathrm{K}_{2} \mathrm{SO}_{4}$, and $\mathrm{KNO}_{3}$.

The application of sludge to land can decrease or increase soil $\mathrm{pH}$, depending on the composition of the sludge. The nitrification of ammonium, hydrolysis of iron ( $\mathrm{Fe}$ ), and aluminum ( $\mathrm{Al}$ ) compounds, and the oxidation of sulfides can all decrease soil $\mathrm{pH}$ depending on crop recovery of nitrates and sulfates. The addition of lime in the biological treatment process to stabilize the sludge can increase soil $\mathrm{pH}$, and minerals and organic matter present in the sludge can increase the $\mathrm{pH}$ buffering capacity of the soil. Alkalinity may also contribute to lowering sludge $\mathrm{P}$ availability.

The concentration of nutrients in compost produced from household, garden and park waste are generally much lower than for sludges and biosolids, in the range 7-28 g/ $/ \mathrm{kg}$ for total N, 0.6-7.0 g/ $\mathrm{kg}$ for total P, and 4-19 g/ $\mathrm{kg}$ for K, on a dry matter basis. Like for sludges, these composts release the organically bound nutrients (mainly $\mathrm{N}$ and $\mathrm{S}$ ) slowly and thus the main reason for applying such composts may be as a soil conditioner rather than for the supply of nutrients. This applies mainly for $\mathrm{N}$ and the literature has documented examples of $\mathrm{N}$ fertilizer equivalent values in the order of $10 \%$ or less compared to inorganic fertilizers.

Although sewage sludges, biosolids and compost contain contaminants such as metals, some commercial mineral fertilizers also contain small amounts of contaminants. While $\mathrm{N}$ and $\mathrm{K}$ fertilizers rarely contain pollutants in any significant amounts, $\mathrm{P}$ fertilizers potentially contain contaminants such as $\mathrm{Cd}$, fluorine $(\mathrm{F})$, strontium $(\mathrm{Sr})$, arsenic (As), $\mathrm{Pb}$, and mercury $(\mathrm{Hg})$, depending on the origin of the ingredients, phosphate rock, and sulfuric acid (McLaughlin et al., 1996). For example primary rock phosphate from the Kola peninsula (Russia) has a high Sr content, but it contains less $\mathrm{Cd}$, chromium $(\mathrm{Cr})$, nickel $(\mathrm{Ni})$, and zinc $(\mathrm{Zn})$ than secondary rock phosphates from other locations, e.g. Morocco, the largest phosphate deposits in the world. When assessing ecotoxicological impacts from waste application, the relative substitution of not only plant nutrients, but also possible contaminants as metals, should be included.

\subsubsection{Potential Pollutants}

Organic wastes contain various contaminants (metals, organics) that may be present in concentrations and/or forms which pose potential environmental and human health risks. Chemical residues in solid organic wastes are characterized by their relatively high ability to adsorb to waste particles and by not being fully mineralized during the retention time during processing.

\subsubsection{Heavy Metals and Metalloids}

Many metals and metalloids are toxic in the soil environment, even at rather low concentrations ( $\mu$ mol $/ \mathrm{kg}$ soil). It is generally accepted that metals having a specific gravity (weight per unit volume) greater than $5 \mathrm{Mg} / \mathrm{m}^{3}$ are termed heavy metals. In soils, these elements include $\mathrm{Cd}, \mathrm{Co}, \mathrm{Cr}, \mathrm{Cu}, \mathrm{Fe}, \mathrm{Hg}, \mathrm{Mn}, \mathrm{Mo}, \mathrm{Ni}, \mathrm{Pb}$, and $\mathrm{Zn}$. Some heavy metals are essential for either plant or animal survival on land ( $\mathrm{Co}, \mathrm{Cr}, \mathrm{Cu}, \mathrm{Fe}, \mathrm{Mn}, \mathrm{Mo}, \mathrm{Ni}, \mathrm{Zn}$ ) while others are not essential and are toxic at low concentrations $(\mathrm{Cd}, \mathrm{Hg}, \mathrm{Pb})$. The toxicity of heavy metals varies from one element to another, and is mainly related to substitution of essential metal cations in enzymes and other vital biomolecules which thereby violates the normal biochemical function.

The heavy metals $\mathrm{Cd}, \mathrm{Cu}, \mathrm{Hg}, \mathrm{Ni}, \mathrm{Pb}$, and $\mathrm{Zn}$ are of major interest when applying waste to land in the industrialized countries, as these elements are found in most wastes originating from industrialized societies and the exposure to humans in some situations is relatively high. In most countries, limits for these and also the metalloids As, Cr, Mo, and 
Table 9.10.3 Guidelines for controlling metal concentrations in soils for reuse of biosolids in USA (EPA 1993) and Europe (CEC 1986), from McLaughlin et al. (2000b).

\begin{tabular}{|c|c|c|c|c|c|c|c|}
\hline \multirow[b]{2}{*}{ Pollutant } & \multicolumn{4}{|c|}{ EPA } & \multicolumn{3}{|c|}{$\mathrm{CEC}^{\mathrm{a}}$} \\
\hline & $\begin{array}{l}\text { Limit } \\
\text { concentration } \\
\text { for biosolids }{ }^{b} \\
(\mathrm{mg} / \mathrm{kg})\end{array}$ & $\begin{array}{l}\text { Cumulative } \\
\text { loading limit } \\
\qquad(\mathrm{kg} / \mathrm{ha})\end{array}$ & $\begin{array}{c}\text { Limit } \\
\text { concentration for } \\
\text { 'safe biosolids'c } \\
(\mathrm{mg} / \mathrm{kg})\end{array}$ & $\begin{array}{l}\text { Annual } \\
\text { loading limit } \\
\text { (kg/ha/year) }\end{array}$ & $\begin{array}{l}\text { Soil MPC } \\
\quad(\mathrm{mg} / \mathrm{kg})\end{array}$ & $\begin{array}{l}\text { Biosolid MPC } \\
\quad(\mathrm{mg} / \mathrm{kg})\end{array}$ & $\begin{array}{c}\text { Annual } \\
\text { loading limit } \\
\text { (kg/ha/year) }\end{array}$ \\
\hline As & 75 & 41 & 41 & 2.0 & & & \\
\hline $\mathrm{Cd}$ & 85 & 39 & 39 & 1.9 & $1-3$ & $20-40$ & 0.15 \\
\hline $\mathrm{Cr}$ & 3000 & 3000 & 1200 & 150 & & & \\
\hline $\mathrm{Cu}$ & 4300 & 1500 & 1500 & 75 & $50-140$ & 1000-1750 & 12 \\
\hline $\mathrm{Pb}$ & 840 & 300 & 300 & 15 & $50-300$ & 750-1200 & 15 \\
\hline $\mathrm{Hg}$ & 57 & 17 & 17 & 0.85 & $1.0-1.5$ & $16-25$ & 0.1 \\
\hline Mo & 75 & 18 & 18 & 0.90 & & & \\
\hline $\mathrm{Ni}$ & 420 & 420 & 420 & 21 & $30-75$ & $300-400$ & 3 \\
\hline $\mathrm{Se}$ & 100 & 100 & 36 & 5.0 & & & \\
\hline $\mathrm{Zn}$ & 7500 & 2800 & 2800 & 140 & $150-300$ & $2500-4000$ & 30 \\
\hline
\end{tabular}

${ }^{a}$ Assumes soil $\mathrm{pH}$ within range $6-7$.

${ }^{b}$ Absolute limit for beneficial use.

${ }^{c}$ Unrestricted use.

${ }^{d}$ MPC: maximum permitted concentration.

eBased on 10-year average.

selenium (Se) are set. Table 9.10.3 compares the metal guidelines for controlling metal concentrations in soils for reuse of sludges/biosolids in the United States and Europe.

Solubility and availability/toxicity to organisms of heavy metal cations $\left(\mathrm{Cd}^{2+}, \mathrm{Cu}^{2+}, \mathrm{Hg}^{2+}, \mathrm{Ni}^{2+}, \mathrm{Pb}^{2+}, \mathrm{Zn}^{2+}\right)$ decreases as soil $\mathrm{pH}$ increases. This is due to the increase in negative charge on variable charge surfaces in soil and the propensity for these metals to precipitate as phosphates, carbonates, and hydroxides as soil $\mathrm{pH}$ increases. In contrast, solubility and availability/toxicity to organisms of anionic metals $\left(\mathrm{CrO}_{4}{ }^{2-}, \mathrm{MoO}_{4}{ }^{2-}\right)$ may increase as soil $\mathrm{pH}$ increases, due again to increases in surface negative charge on soil particles affecting sorption. Under reducing conditions in soil, many of the metals form insoluble metal sulfides, therefore reducing availability to plants and animals.

Metal retention by soil is often described by a partition coefficient, often termed the distribution coefficient $\left(K_{\mathrm{d}}\right)$. This is a measure of the amount of metal retained on the soil particles divided by the concentration of metal in soil solution:

$$
K_{\mathrm{d}}(\mathrm{l} / \mathrm{kg})=\frac{\text { Soil metal }(\mathrm{mg} / \mathrm{kg})}{\text { Solution metal }(\mathrm{mg} / \mathrm{l})}
$$

Thus low $K_{\mathrm{d}}$ values indicate a propensity for leaching and removal from soil (e.g. B, Se), and a high $K_{\mathrm{d}}$ indicates likelihood of high retention time in soil and little transport (e.g. Cr, $\mathrm{Pb}$ ). Cadmium is most mobile in low pH soil within the range $\mathrm{pH} 4.5-5.5$, whereas in alkaline soils $\mathrm{Cd}$ is rather immobile. Based on analysis of 63 Danish soils sampled at three depths, Christensen (1989) found that $72 \%$ of the variation in Cd partitioning $\left(K_{\mathrm{d}}\right)$ could be explained by variations in $\mathrm{pH}$.

Critical exposure pathways for expression of heavy metal toxicity in soil have been examined as part of regulation governing reuse of sewage sludge on soil (EPA 1993). For some elements, e.g. Cd and Co, food chain transfer is the main risk pathway as these elements are easily accumulated by plants in edible tissues. For other elements, sorption in soil is strong, bioaccumulation by microorganisms low and plant uptake and translocation so low that the dominant risk pathway is (for higher animals and humans) through direct ingestion of soil e.g. $\mathrm{Hg}$ and $\mathrm{Pb}$. For the other heavy metals, behavior in soil and bioaccumulation characteristics result in toxicity to plants and microorganisms (phyto- and ecotoxicity) being the dominant risk pathway at high concentrations e.g. $\mathrm{Cr}, \mathrm{Cu}, \mathrm{Mn}, \mathrm{Ni}$, and $\mathrm{Zn}$ (McLaughlin, 2002). Thus, prediction 
of risks from heavy metal pollution of soils through soil testing requires a different emphasis depending on the metal considered (McLaughlin et al., 2000).

Metals which are strongly retained by soil accumulate in the surface soil horizons, and losses by plant uptake/removal and leaching processes, even over decades and centuries, are very small. Holm et al. (1998) studied the leaching output from plant pot experiments with 15 contaminated soils which differed in origin, texture, $\mathrm{pH}(5.1-7.8)$ and concentrations of $\mathrm{Cd}(0.2-17.0 \mathrm{mg} \mathrm{Cd} / \mathrm{kg})$ and $\mathrm{Zn}(36-1300 \mathrm{mg} \mathrm{Zn} / \mathrm{kg})$. Annual leaching outflows were estimated from soil water concentrations to $0.5-17.0 \mathrm{~g} \mathrm{Cd} / \mathrm{ha} /$ year and 9-3600 g Zn/ha/year per $100 \mathrm{~mm}$ of net percolation, corresponding to $0.1 \%$ per year of the total top soil content of $\mathrm{Cd}$ and $\mathrm{Zn}$. Assuming a similar removal by plants/crops the average retention time in the top soil for heavy metals like $\mathrm{Cd}$ and $\mathrm{Zn}$ is several hundred years. For these elements it is critical to ensure that loadings are also small so that build up in the surface soil horizons is avoided. A recent review concluded that the metal content of mechanically segregated MSW compost does not represent a barrier to end use of the product, but that limits on heavy metals in compost may be set to encourage recycling of composted residuals and contaminant reduction measures, which at the same time, also protect the soil and environment from potentially negative impacts caused by long-time accumulation of heavy metals in soil. However, there is no evidence to suggest that risk from metals in MSW composts are lower (per unit metal) than those from metals in biosolids. Most research on risks from metals has been conducted for sewage sludges, and until sound science suggested limits for MSW composts should be otherwise, biosolid-based limits will also be applied to these materials.

\subsubsection{Organic Micropollutants}

The potential number of organic pollutants is very high. Wastes applied on land may contain residues from chemicals used in animal production, industries and households. Most of the organic pollutants are non-ionic and nonpolar which means that they show rather low solubilities in water and sorb strongly to organic matter in soils. Unlike the inorganic pollutants these pollutants may be degraded and fully mineralized or they can be incorporated into soil humic substances and loose their toxicity. However, in most cases sorbed organic pollutants are not readily available for microbial degradation. Hence, substances which are less strongly sorbed to the soil solids are more easily degraded provided they are not toxic to the degraders. The less strongly retained substances are also more easily leached to groundwaters. Degradation of organic substances takes place through a number of steps with formation of a suite of metabolites. As most degradation comprises oxidation processes (in aerobic soils) the metabolites are more or less oxidized, hence they are more polar and less strongly bound in the soil than the parent compound. Metabolites may be as toxic as the parent compounds and hence also provide a threat to soil and groundwater quality.

Detergents are used in large amounts in households and industry. The sources of detergents in soils are mainly sewage sludge. Sewage sludges with highest contents of detergents (up to $10 \mathrm{~g} / \mathrm{kg}$ sludge) come from anaerobic treatment plants as the detergents are rather stable under anaerobic conditions.

Most detergents are rapidly degraded in soils and normally do not represent a threat to soil functions. However, detergents may have some undesired indirect effects in soil, e.g. they can render hydrophobic pesticides, PCBs and PAHs more soluble and thus increase the mobility and bioavailability of these substances.

Drugs and their metabolites are added to soil environments mainly via sludges and animal slurries. Veterinary drugs such as growth promoters contribute the largest amount of drugs added to soils and may cause soil concentrations of $>0.1 \mathrm{mg} / \mathrm{kg}$. Drugs may pass through the animals and storage unchanged or only slightly modified and hence may de disposed to soil in a still-active form. There is much concern about antibiotics in soil due to the risk of inducing resistance to antibiotics among soil bacteria. In general, very few physicochemical properties for drugs have been determined or are available in the literature. Some of these compounds sorb to soils whereas others are mobile.

Polychlorinated biphenyls (PCBs) have been used in electrical equipment due to their insulating and heat conducting properties. Manufacturing stopped in the 1970s. PCBs have also been used as a plasticizer, as lubricants and as fireproofing agents. PCBs in soils mostly originate from sewage sludge. The PCBs are quite resistant to degradation; the more highly chlorinated being the most resistant. In general the compounds are strongly bound in soils.

The information about dioxins in biologically treated organic wastes is very scarce and dioxin originates mainly from chemical processes involving chlorine and from combustion processes. 
Polycyclic aromatic hydrocarbons (PAHs) consist of fused benzene rings, and thus only contain carbon and hydrogen. The family of PAHs is very large but the PAHs of environmental concern do not contain more than seven benzene rings. Large amounts of PAHs are formed during combustion processes in power plants, incinerators, open burning, and motor vehicles. Processes producing tars also contain heteroaromatics, i.e. compounds which in addition to $\mathrm{C}$ and $\mathrm{H}$ also contains N, S, and/or O. Important exposures of PAHs from waste application to land are sewage sludges and composts, but there may be large local variation according to distance to industrial plants, cities, etc.

Many other organics such as pesticides, oils, and chlorinated solvents may end up in the soil environment as a consequence of anthropogenic activities. However, these compounds are not directly related to application of processed organic waste to land and thus not covered in this chapter. One final group to mention is the group of natural toxins. A large number of plants and microorganisms produce metabolites which are toxic. Plants produce such substances in order to compete with other species in the defense against attack by fungi and insects. These toxins and new industrial chemicals, e.g. flame retardants, hormone-like substances, and new persistent pharmaceuticals (including formulated nanoproducts) may also be found in processed organic waste, but the fate of these compounds in the soil environment is not yet known.

\subsubsection{Quality Requirements and Critical Exposure of Material Utilized}

Regulations and practices to control organic waste recycling into agriculture often reflect local political and community opinions on acceptable quality of the material and attitudes to risk. Generally, regulations include limits concerning quantities of waste applied to land and frequency of application (annually and total applied quantities) and quality (chemical, physical, and biological characteristics, ratio of agronomic value to pollutant content). As an example, legislation in Denmark defines the maximum amounts of $\mathrm{N}$ and $\mathrm{P}$ application per hectare allowed annually to land as sludges and manure. Other measures are voluntary or mandatory pretreatment of waste to improve its quality (e.g. aeration, composting) and the use of good management practices at land application sites (e.g. season for application, establishment of buffer zones).

Often one of the following three basic approaches to setting limits can be distinguished (McGrath et al., 1994):

1. Comprehensive analyzing the exposure routes of pollutant transfer to selected target organisms and assessing the likely harmful effects that the pollutants may have on the targets.

2. Setting limits consistent with the lowest observed adverse effect concentrations, which are actual cases of effects due to pollutants.

3. Attempting (for metals only) to match the metal inputs to soil to the small output or losses of metals due to crop removal, soil erosion, and leaching, the sustainable criterion (see also Box 9.10.3).

These differing approaches have different and sometimes inconsistent numerical limits being set for the same constituents across various jurisdictions.

Table 9.10.4 presents exposure pathways and impacts in relation to environmental pathways of concern in the use of organic waste on land. For agricultural use of wastes, the most important exposure routes are 4-9 in Table 9.10.4, and much research has been conducted on these pathways.

Although standards and legislation for use and application of sewage sludges and other processed organic wastes were created for the safe use of these organic wastes, public concern about the negative effect that the disposal of these solids may have on public health is frequently voiced. However, a number of studies on impacts from land application of waste, in compliance with these standards and regulations, consistently indicate no detrimental effects, rather improvements in soil quality due to the input of organic matter (e.g. Petersen et al., 2003; Gibbs et al., 2006; Smith, 2009). Generally these studies are short term however, and regulations and guidelines must consider time scales of decades or centuries, as has been pointed out by Giller et al., (2009) with respect to long-term sensitivity of soil microorganisms, and that the bioavailability and hence toxicity will be moderated by ageing, leaching and soil type (Smolders et al., 2009). 
Table 9.10.4 Exposure routes of concern when using organic waste on land.

\begin{tabular}{lll}
\hline & Exposure pathway & Description of impact, example \\
\hline 1 & Waste - Human & $\begin{array}{c}\text { Humans (children) ingesting waste containing pathogens, organic } \\
\text { pollutants or metals. } \\
\text { Human breathing volatile pollutants from land-applied waste }\end{array}$ \\
2 & Waste - Soil - Air - Human & $\begin{array}{l}\text { Tractor operator exposed to dust while ploughing waste-applied land } \\
\text { Humans ingesting crops with increased pollutant content }\end{array}$ \\
4 & Waste - Soil - Airborne dust - Human & Humans eating animals feed with plants containing pollutants. \\
5 & Waste - Soil - Plant - Human & Yield of crop plants being affected negatively by waste-borne plant \\
6 & Waste - Soil - Plant - Animal - Human & pathogens, pests, weed seeds and metal toxicity. \\
7 & Waste - Soil - Soil organism & $\begin{array}{l}\text { Metal or organic pollutant effecting the soil microbe functionality } \\
\text { Toxicity to animals ingesting soil from waste treated land }\end{array}$ \\
8 & Waste - Soil - Animal & $\begin{array}{c}\text { Potable water polluted by surface runoff or leaching from } \\
\text { waste-treated land. }\end{array}$ \\
9 & Waste - Soil - Surface/groundwater - Human & \\
\hline
\end{tabular}

\subsubsection{Practical Utilization of Organic Waste as a Nutrient Source}

Besides the technical, legislative, and environmental considerations of use of treated waste in agriculture, the economics must also be considered. The operation should fully calculate all the operational costs and the information on the economic value of greater crop yields, and/or savings on fertilizer. Some of the most significant economic factors to consider are:

1. The proximity of the agricultural land relative to the waste production site and if dewatering or drying of the waste material is favored.

2. If the waste is not available when needed, can they be stored, are storage facilities available, and who will provide them.

3. The cost and availability of machinery for transporting and applying the waste. Provided waste is properly treated to reduce water content and to attain good physical characteristics (bulk density, aggregation, etc.), no special equipment is needed for application to land and conventional agricultural equipment can be used.

4. Whether the farmer is willing to receive the waste without payment; in some countries/regions alternative treatment cost may enable farmers to demand a 'gate fee' for receiving the waste, as a compensation for any additional trouble with the handling of the waste, even if he saves fertilizer and enhances crop yields.

Whether the material is MSW compost, sewage sludge, or farm manure, several general principles apply to the sustainable sound application of the material to soils. Land application rates of the waste products depend on nutrient and water content of the treated organic waste and the application context (crop type, nutrient demand, etc.). The rate of application is generally governed by the amounts of $\mathrm{N}$ or $\mathrm{P}$ that the organic material will make available to plants. $\mathrm{N}$ usually is the first criterion because it is needed in the largest quantity by most plants, and because excess $\mathrm{N}$ often will represent a leaching risk. However, the $\mathrm{P} / \mathrm{N}$ ratio in most organic wastes is higher than crop requirements. Consequently, if the organic waste material is applied in accordance with crop $\mathrm{N}$ requirements, excessive levels of soil $\mathrm{P}$ will result. While $\mathrm{P}$ is strongly bound in soils, a long-term view is needed and the risk of surface runoff of $\mathrm{P}$ is likely. For soils that already have high levels of P, e.g. from inorganic fertilizers, the amount of an organic nutrient source applied may be limited by its $\mathrm{P}$ content.

A small fraction of the $\mathrm{N}$ in manure or sludge may be inorganic and immediately available to plants, but the bulk of the $\mathrm{N}$ is organic and must be released by microbial mineralization of organic matter. The organic waste materials have already released a part of its $\mathrm{N}$ through partially degrading during treatment and handling.

For nutrient-rich waste products like sludge and other biosolids, the application rate will often be limited by regulations on maximum $\mathrm{N}$ or P loads (Pierzynski and Gehl, 2005). Typical rates are in the range 1-10 Mg dry matter/ha, corresponding to 3-50 Mg wet weight/ha (Gilmour et. al. 2003). For more nutrient-poor materials like household or green waste compost, 
application rates may be somewhat higher, e.g. 50-100 Mg wet weight/ha. The nutrient and moisture contents of organic waste materials vary widely among sources, and they also depend on how the material has been stored and treated. Therefore, a representative sample of the material should be analyzed in a laboratory, if this information is not provided by the supplier. Analyses are generally required by laws regulating land application of waste materials.

When land is treated annually with an organic material, the application rate needed will become progressively smaller because, after the first year, the amount of $\mathrm{N}$ released from material applied in previous years must be subtracted from the total to be reapplied. This is especially true for composts for which the initial availability of the $\mathrm{N}$ is quite low. Instead of making progressively smaller applications, another practical strategy is to use a moderate rate every year, but supplement the $\mathrm{N}$ from other sources in the first few years until $\mathrm{N}$ release from residual previous applications can supply the entire crop requirement.

In some countries or regions, the controls on agricultural use of wastes have become so strict that options such as incineration or gasification are more viable, if not only for economic reasons, then for security of solutions and independence of farmers willing to receive the waste. As an example, Switzerland in 2003 introduced a ban on land application of sewage sludge, first for fodder crops and vegetables, from 2006 extended to all arable land (Anonymous, 2003), and today nearly all sewage sludge in Switzerland is incinerated.

\subsubsection{Future Perspectives}

It is likely that increasing volumes of waste will be produced by urban centres and by industries. Given the incentives for recycling and full life cycle assessment (LCA) of industrial processes, it is likely that land application and beneficial reuse of wastes will be encouraged. The lack of suitable landfill space in Europe will also provide a strong incentive to develop beneficial reuse options for wastes. However, it will be important that all actual positive and negative impacts are taken in to consideration, e.g. through a LCA. It is important that such an LCA is carried out for the local settings and at the right scale, as the result may be highly influenced by this. As an example, Bruun et al. (2006) and Hansen et al. (2006) used a land application model dealing with agricultural application of residues from composting or anaerobic digestion of organic MSW and found that the local agricultural conditions (soil type, rainfall, farm type) had a strong influence on the resulting environmental impact and fertilizer $\mathrm{N}$ and $\mathrm{P}$ substitution (see Box 9.10.2 for further details). Therefore, LCA of alternative options for organic waste disposal, including land application, should always include a careful model analysis of the land use effects, including not only direct emissions, but also secondary effects like changes in crop productivity, soil C sequestration, etc.

Methods to detect contaminants in wastes have improved dramatically, and research into the potential adverse effects of contaminants on humans or the ecosystem is continuously improving the risk assessments relating to land reuse of waste. Much is already known regarding the fate and effects of metals and nutrients. Contaminants are perhaps best controlled at source, where technologies are developed to remove the highest risk contaminants from the waste stream so that land reuse is more feasible. At the same time, waste processing needs to take into account the intended end use of the product, and additional processing (e.g. nutrient addition) may be needed to provide a material that is more suitable and 'fit for purpose'. Nevertheless, the most hazardous wastes will still need to be treated by incineration or land disposal.

An increase in quality (decreases in the concentrations of salt and undesirable elements, e.g. $\mathrm{Cd}, \mathrm{Hg}, \mathrm{Pb}$ ) of organic wastes and adequate quality control would make them more competitive with chemical fertilizer and other soil amendments like peat-based growth media and other soil ameliorants. Conservation of the $\mathrm{N}$ that usually volatilizes as $\mathrm{NH}_{3}$ during waste treatment would greatly increase the value of many products. Improvements in the physical condition of many waste products for better control and accurate application would also be helpful. Similarly, reduction of odours will assist acceptance by the public and farmers.

Perhaps the greatest gap in our knowledge will be the fate and effects of some of the new industrial chemicals, e.g. flame retardants, hormone-like substances, new persistent pharmaceuticals, personal care products, and nanomaterials. It is important that research understands the fate and effects of these chemicals in the environment prior to any waste containing these contaminants being applied to land. 


\section{References}

Andersen, M.K., Refsgaard, A., Raulund-Rasmussen, K., Strobel, B.W. and Hansen, H.C.B. (2002): Content, distribution, and solubility of cadmium in arable and forest soils. Soil Science Society of America Journal 66, 1829-1835.

Anonymous (2003): Ban on the use of sludge as a fertiliser. Press release of 26 March. Federal Department of Environment, Transport, Energy and Communications, Zurich, Switzerland.

Avery, L.M., Killham, K. and Jones, D.L. (2005): Survival of E. coli O157:H7 in organic wastes destined for land application. Journal of Applied Microbiology 98, 814-822.

Binder, D.L., Dobermann, A., Sander, D.H. and Cassman, K.G. (2002): Biosolids as nitrogen source for irrigated maize and rainfed sorghum. Soil Science Society of America Journal 66, 531-543.

Brandt, K.K., Petersen, A., Holm, P.E., Nybroe, O. (2006): Decreased abundance and diversity of culturable Pseudomonas populations with increasing copper exposure in the sugar beet rhizosphere. FEMS Microbiology Ecology 56, 281291.

Bruun, S., Hansen, T.L., Christensen, T.H., Magid, J., Jensen, L.S. (2006): Application of processed organic municipal solid waste on agricultural land - a scenario analysis. Environmental Modeling and Assessment 11, 251-265.

Carrington, E.G. (2001): Evaluation of sludge treatments for pathogen reduction - final report. Report No. 5026/1. European Commission, Brussels, Belgium.

Christensen, T.H. (1989): Cadmium soil sorption at low concentrations: VIII. Correlation with soil parameters. Water, Air, and Soil Pollution 44, 71-82.

Dahiya, R., Malik, R.S. and Jhorar, B.S. (2001): Organic mulch decomposition kinetics in semiarid environment at bare and crop field conditions. Arid Land Research and Management, 15, 49-60.

EPA (1993): Part 503 - Standards for the use and disposal of sewage sludge. United States Environment Protection Agency. Federal Register 58, 9387-9404.

Epstein, E. (2003): Land application of sewage sludge and biosolids. Lewis Publishers, New York, USA.

FAO (2008): Current world fertilizer trends and outlook to 2012. Food and Agriculture Organization of the United Nations, Rome, Italy.

Gibbs, P.A., Chambers, B.J., Chaudri, A.M., McGrath, S.P., Carlton-Smith, C.H., Bacon, J.R., Campbell, C.D. and Aitken, M.N. (2006): Initial results from a long-term, multi-site field study of the effects on soil fertility and microbial activity of sludge cakes containing heavy metals. Soil Use and Management, 22, 11-21.

Giller, K.E., Witter, E., McGrath, S.P. (2009): Heavy metals and soil microbes. Soil Biology Biochemistry, 41, 2031-2037.

Gilmour, J.T., Cogger, C.G., Jacobs, L.W., Evanylo, G.K., and Sullivan, D.M. (2003): Decomposition and plant-available nitrogen in biosolids: Laboratory studies, field studies, and computer simulation. Journal of Environmental Quality, 32, 1498-1507

Hansen, H.C.B. (2001): Environmental soil chemistry. Leonardo da Vinci Programme. Mataj Bel University, Banská Bystrica, Slovakia.

Hansen, T.L., Bhander, G.S., Christensen, T.H., Bruun, S. and Jensen, L.S. (2006): Life cycle modeling of environmental impacts of application of processed organic municipal solid waste on agricultural land (EASEWASTE). Waste Management Research 24, 153-166.

Hedley, M.J. and McLaughlin, M.J. (2005) Reactions of phosphorus fertilizers and by-products in soils. In: 'Phosphorus in Agriculture.' Monograph, American Society of Agronomy/Soil Science Society of America, Madison, USA.

Holm, P.E., Christensen, T.H., Lorenz, S.E., Hamon, R.E., Domingues, H.C., Sequeira, E.M. and McGrath, S.P. (1998): Measured soil solution concentrations of cadmium and zinc in plant pots and estimated leaching outflows from contaminated soils. Water, Air and Soil Pollution 102, 105-115.

Kirkeby, J.T., Hansen, T.L., Birgisdottir, H., Bhander, G.S., Hauschild, M. and Christensen, T.H. (2006): Environmental assessment of solid waste systems and technologies: EASEWASTE. Waste Management and Research, 24, 3-15.

Magid, J., Eilersen, A.M., Wrisberg, S. and Henze, M. (2006): Possibilities and barriers for recirculation of nutrients and organic matter from urban to rural areas: A technical theoretical framework applied to the medium-sized town Hillerød, Denmark. Ecological Engineering 28, 44-54.

McGrath, S.P., Chang, A.C. and Page, A.L. (1994): Land application of sewage sludge: Scientific perspectives of heavy metal loading limits in Europe and the United States. Environmental Review, 2, 108-118. 
McLaughlin, M.J. (2002): Heavy metals. In: Lal, R. (ed.) ‘Encyclopedia of Soil Science.’ Marcel Dekker Inc., New York, USA.

McLaughlin, M.J. and Champion, L. (1987): Sewage sludge as a phosphorus amendment for sesquioxic soils. Soil Science, $143,113-119$.

McLaughlin, M.J., Tiller, K.G., Naidu, R. and Stevens, D.G. (1996): Review: The behaviour and environmental impact of contaminants in fertilizers. Australian Journal of Soil Research, 34, 1-54.

McLaughlin, M.J., Zarcinas, B.A., Stevens, D.P. and Cook, N. (2000a): Soil testing for heavy metals. Communications in Soil Science and Plant Analysis, 31, 1661-1700.

McLaughlin, M.J., Hamon, R.E., McLaren, R.G, Speir, T.W. and Rogers, S.L. (2000b): Review: A bioavailabilitybased rationale for controlling metal and metalloid contamination of agricultural land in Australia and New Zealand. Australian Journal of Soil Research, 38, 1037-1086.

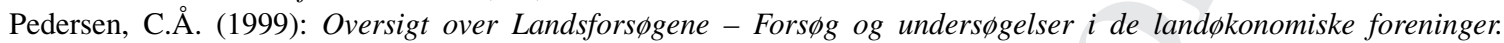
Landbrugets Rådgivningscenter (Report on the agricultural field trials conducted by the Danish Agricultural Advisory Service; in Danish). Reports 1993-1999. Located on the internet: 19 July 2007. www.lr.dk/planteavl.

Petersen, J. (1996): Husdyrgødning og dens anvendelse (Animal manure and its use; in Danish). SP Rapport no. 11. Statens Planteavlsfors $\varnothing \mathrm{g}$, Copenhagen, Denmark.

Petersen, J. (2003): Nitrogen fertilizer replacement value of sewage sludge, composted household waste and farmyard manure. Journal of Agricultural Sciences, 140, 169-182.

Petersen, S.O., Henriksen, K., Mortensen, G.K., Krogh, P.H., Brandt, K.K., Sørensen, J., Madsen, T., Petersen, J. and Grøn, C. (2003): Recycling of sewage sludge and household compost to arable land: fate and effects of organic contaminants, and impact on soil fertility. Soil and Tillage Research, 72, 139-152.

Pierzynski, G.M. and Gehl, K.A. (2005): Plant nutrient issues for sustainable land application. Journal of Environmental Quality, 34, 18-28.

Poulsen, H.D. (2009): Normtal for husdyrgødning - 2009 (Animal manure norms for nutrient content - 2009; in Danish). Internal report. Faculty of Agricultural Sciences, University of Aarhus, Denmark.

Preusch, P.L. and Tworkoski, T.J. (2003): Nitrogen and phosphorus availability and weed suppression from composted poultry litter applied as mulch in a peach orchard. Hortscience, 38, 1108-1111.

Saison, C., Degrange, V., Oliver, R., Millard, P., Commeaux, C., Montagne, D. and Roux, X.L. (2006): Alteration and resilience of the soil microbial community following compost amendment: effects of compost level and compost-borne microbial community. Environmental Microbiology, 8, 247-257.

Shiralipour, A., Mcconnell, D. and Smith, W. (1992): Uses and benefits of MSW compost - A review and an assessment. Biomass and Bioenergy, 3, 267-279.

Smith, P., Goulding, K.W., Smith, K.A., Powlson, D.S., Smith, J.U., Falloon, P. and Coleman, K. (2001): Enhancing the carbon sink European agricultural soils: including trace gas fluxes in estimates of carbon mitigation potential. Nutrient Cycling in Agrosystems, 60, 237-252.

Smith, S.R. (2009): A critical review of the bioavailability and impacts of heavy metals in municipal solid waste compared to sewage sludge. Environmental International, 35, 142-156.

Smolders, E., Oorts, K., Van Sprang, P., Schoeters, I., Janssen, C.R., McGrath, S.P. and McLaughlin, M.J. (2009): The toxicity of trace metals in soil as affected by soil type and ageing after contamination: using calibrated bioavailability models to set ecological soil standards. Environmental Toxicology and Chemistry, 28, 1633-1642.

Steen I. (1998): Phosphate recovery - Phosphorus availability in the 21st century - Management of a non-renewable resource. Phosphorus and Potassium, 217.

Stevenson, F.J. and Cole, M.A. (1999): Cycles of soil. Carbon, nitrogen, phosphorus, sulfur, micronutrients, 2nd edn. John Wiley \& Sons, Ltd, New York, USA.

Strauch, D. (1998): Pathogenic micro-organisms in sludge. Anaerobic digestion and disinfection methods to make sludge usable as a fertiliser. European Water Management, 1, 12-26.

Tian, G., Granato, T.C., Cox, A.E., Pietz, R.I., Carlson, C. Jr. and Abedin, Z. (2009): Soil carbon sequestration resulting from long-term application of biosolids for land reclamation. Journal of Environmental Quality, 38, 61-74.

Weggler, K., McLaughlin, M.J. and Graham, R.D. (2004): Effect of chloride in soil solution on the plant availability of biosolid-borne cadmium. Journal of Environmental Quality, 33, 496-504. 